\title{
PÉTER SOMFAI
}

Eötvös Loránd University of Science

\section{The Loss of Innocence \\ Catullan Intertexts in Vergil's Eclogue 8 and the Camilla Episode of the Aeneid}

In ancient Rome, some elements of the wedding ritual (e.g. the raptio or the defloration) could be associated with aggression and death. In Catullus 62 and 66 - two poems dealing with the topic of marriage -, these connotations get a special emphasis, in part due to the motif of cutting symbolizing violence and changing. In this paper, I examine the way the above mentioned poems constitute the background for the allusion to Medea in Vergil's Eclogue 8 and the depiction of Camilla in Book 11 of the Aeneid. It will be of fundamental importance to observe the way aggressiveness - being a traditional characteristic of men - gets transferred to women, by means of intertextual connections.

Keywords: Vergil, Catullus, marriage, death, gender roles, intertextuality

The Roman wedding ritual presents itself as an excellent example of the phenomenon called rite of passage by Arnold van Gennep, ${ }^{1}$ as, on the one hand, maidens were taken out of their biological family during it, ${ }^{2}$ and, on the other hand, they became adults by means of losing their virginity if they married for the first time. ${ }^{3}$ Because of these significant sexual and existential changes coming about during the rite, it seems that maidens were expected to be - or at least to pretend to be - terrified about their wedding night. ${ }^{4}$ Some elements of the wedding ritual, e.g.

\footnotetext{
* The present article was written with the support of the project "The Margins of Ancient Lyric Poetry" (NKFI FK 128492). My thanks go to my anonymous lector for helping me by making remarks on my study.

${ }^{1}$ GENNEP (1909).

${ }^{2}$ HubBARD (2014: 77).

${ }^{3}$ In ancient Rome it was a fundamental standard imposed on maidens to preserve their virginity until their first marriage, see HERSCH (2010: 61).

4 HERSCH (2010: 64).
} 
the practice of raptio or the summoning of Hymenaeus could help the bride to come up to this expectation, as violence could be associated with the former one ${ }^{5}$ and death with the latter. ${ }^{6}$ Furthermore, these associations could also emerge in accordance with the idea that defloration connotes bloodshed and murder, as the rupture of the hymen is often followed by bleeding. ${ }^{7}$

Thanks to these connotations, it appears that in the Catullan 'long poems' - primarily in poems 62 and 66 - the loss of innocence in the sexual sense is intertwined with the motives of aggression, violence and even murder, or in other words, with the thought of the loss of innocence in the legal sense. By means of intertextual connections with the Catullan poems in question, this phenomenon can also be noticed in Vergil's Eclogue 8 and some passages of the Aeneid dealing with the topic of marriage, e.g. the lines of Book 11 describing Camilla. The purpose of my study is to examine the intertextual interplay of the passages mentioned above, as it will be of essential importance to observe the way the issue of marriage occurs - reflecting the influence of Catullus - in the works of Vergil, which was not trouble-free in itself at all and received special attention in the Augustan discourse, thanks to e.g. the marital laws called lex Iulia de maritandis ordinibus accepted in $18 \mathrm{BC}$ and lex Iulia de adulteriis coercendis adopted a year later. Due to the nature of intertextuality, as the act of reception plays an important role in the formation of meaning, I only claim to present 'possible' but not 'peremptory' readings of the intertexts in question.

Scholars are divided regarding the ritual context of Catullus 62, the poem being the starting point of my analysis, as it seems that the ritual act it represents (or creates) ${ }^{8}$ cannot be connected with any particular aspect of the Roman (or Greek) wedding ritual. ${ }^{9}$ However, its form of a carmen amoebaeum, i.e. a singing contest between the choruses of young

\footnotetext{
5 PANOUSSI (2007: 278).

${ }^{6}$ Hersch (2010: 237).

${ }^{7}$ MitCHELL (1991: 221-222).

${ }^{8}$ For the representativeness and nature of a speech act of the lyric genre see CULLER (2015: 35-37).

9 PANOUSSI (2007: 277).
} 
boys and maidens - which can be associated with some Greek wedding rites - and allusions to an ancient Roman ritual practice, the raptio, obviously place the poem in the context of a wedding ritual. ${ }^{10}$ When the girls start their speech denoting the actual beginning of the contest, ${ }^{11}$ they complain about Hesperus, the Evening Star the following way:

Hespere, quis caelo fertur crudelior ignis?

qui natam possis complexu avellere matris, complexu matris retinentem avellere natam et iuveni ardenti castam donare puellam.

Quid faciunt hostes capta crudelius urbe?

(Cat. carm. 62, 20-24)

Hesperus, what more cruel fire moves in the sky? for thou canst endure to tear the daughter from her mother's embrace, from her mother's embrace to tear the clinging daughter, and give the chaste maiden to the burning youth. What more cruel than this do enemies when a city falls?

(Transl. F. Warre Cornish)

Hesperus is presented as the cruelest light in the sky as he has the heart to tear the innocent (castam) daughter from the embrace of her mother and to hand her over to the ardent youth - which is such a great savageness that even an enemy does not do anything more dreadful after capturing a city. The momentum of tearing apart recalls the ritual practice of raptio (or raptus simulatus) known from the classical descriptions of Festus and Macrobius, which took part at the start of the phase of the wedding ceremony called deductio - i.e. the transition of the bride from the parental house to the home of her future husband ${ }^{12}-$ and during which the daughter was symbolically torn from the lap/embrace of her mother. As this custom was traced back to an eminently violent event, the legendary abduction of the Sabine women, ${ }^{13}$ the allusion to it

\footnotetext{
10 PANOUSSI (2007: 277).

11 THOMSEN (2002: 20).

12 PANOUSSI (2007: 277).

13 PANOUSSI (2007: 277).
} 
can obviously be associated with the idea of aggression. However, thanks to the mentioning of Hesperus, another disquieting association might also emerge in the reader. The addressee of the maidens' 'complaint' in Catullus 62 can be matched with Hymenaeus, ${ }^{14}$ the 'god of wedding' addressed in the poem's refrain (Hymen o Hymenaee, Hymen ades o Hymenaee!) on the basis that he is the one appearing in Catullus 61 who carries away the tender virgin to the man (qui rapis teneram ad virum / virginem, carm. 61, 3-4) and gives the blooming girl from her mother's lap into the hands of a wild youth ( $t u$ fero iuveni in manus / floridam ipse puellulam / dedis a gremio suae / matris, carm. 61, 56-59). The figure of Hymenaeus can also be related with death, as, on the one hand, we know about a youth bearing this name from Greek literary sources who died during his wedding night, ${ }^{15}$ and, on the other hand, as wedding is a transition from one sphere of existence to another, so, as a matter of fact, the before-the-wedding ego dies in order to start a new life in the otherworld of the marriage. ${ }^{16}$ Therefore, his name is included in several funerary poems from the Hellenistic age which commemorate youths or girls who have died before their wedding. ${ }^{17}$ Servius' commentary on the Aeneid mentions another Hymenaeus as well who had been such a handsome Athenian youth that on one occasion, when he participated in the Eleusinian Mysteries, pirates attacking the assembled took him for a girl and abducted him. The youth murdered them while they were asleep and, as a reward, had the honor to be allowed to marry a noble Athenian girl. ${ }^{18}$ So, the motif of wedding and death are interconnected in both stories, thus, by means of addressing Hymenaeus in the epithalamium, the idea of death also gets recalled.

After the youths have answered the girls' 'complaint' by emphasizing the positive features of the activity of Hesperus, the maidens start speaking again with the following simile:

\footnotetext{
14 THOMSEN (2002: 16).

${ }^{15}$ HERSCH (2010: 237).

16 SZILÁGYI (2011: 239).

17 HERSCH (2010: 237).

18 HERSCH (2010: 238).
} 
Ut flos in saeptis secretus nascitur hortis, ignotus pecori, nullo convolsus aratro, quem mulcent aurae, firmat sol, educat imber, multi illum pueri, multae optavere puellae; idem cum tenui carptus defloruit ungui, nulli illum pueri, nullae optavere puellae: sic virgo, dum intacta manet, dum cara suis est; cum castum amisit polluto corpore florem, nec pueris iucunda manet, nec cara puellis.

(Cat. carm. 62, 39-47)

As a flower springs up secretly in a fenced garden, unknown to the cattle, torn up by no plough, which the wind caress, the sun strengthens, the shower draws forth, many boys, many girls, desire it; when the same flower fades, nipped by a sharp nail, no boys, no girls, desire it: so the maiden, whilst she remains untouched, so long she is dear to her own; when she has lost her chaste flower with sullied body, she remains neither lovely to boys nor dear to girls.

(Transl. F. Warre Cornish)

The flower growing in an enclosed garden, being safe from animals and plow is desired by many boys and girls (multi illum pueri, multae optavere puellae) until it remains untouched, but after it gets plucked and fades nobody yearns for it. Similarly, the maiden is only desirable until she keeps her 'chaste flower' (castum... florem), but when her body gets stained (polluto corpore) she loses her charm. The motif of the fading of a fragile flower symbolizing youth, beauty and innocence being the metaphor of losing virginity can be traced back to Sappho's fragment 105c, ${ }^{19}$ which - according to some scholars - can also be related with the topic of wedding, and in which shepherds tread down a purple hyacinth. ${ }^{20}$ However, the Sapphic image depicting manly destructiveness and aggression is not only recalled by Catullus' poem 62 but also by the last stanza of poem 11:

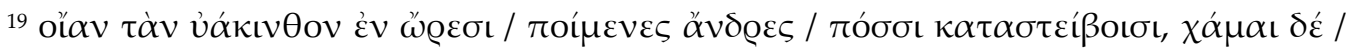

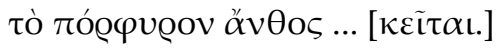

20 GREENE (2007: 145).
} 
nec meum respectet, ut ante amorem

qui illius culpa cecidit velut prati

ultimi flos, praetereunte postquam

tactus aratro est.

(Cat. carm. 11, 21-24)

and let her not look to find my love, as before; my love, which by her fault has dropped, like a flower on the meadow's edge, when it has been touched by the plough passing by.

(Transl. F. Warre Cornish)

In the quoted passage, the poet complains about Lesbia not having respect for his love felt for her, which perishes due to her fault as a flower on the edge of a field, mowed by a plow passing by (praetereunte postquam / tactus aratro est). As the flower is a well-known metaphor of a maiden and female virginity in the Greek and Roman literature, so is the plow that of a male phallus, but, in this case, against the regular motif implying the violent dominance of the man, the sexual roles are reversed: Catullus depicts himself deflowered by a 'mascula Lesbia', at least in the figurative sense. ${ }^{21}$ So, while plucking/cutting symbolizes both the separation from the former milieu and the transition from an unmarried - and therefore a virgin - status into a married - i.e. noninnocent - one in Catullus 62, it might result in a completely different kind of change in Catullus 11: the change of the gender. ${ }^{22}$ This change of the gender roles will be of essential importance in the case of the Vergilian texts recalling more than one Catullan poem simultaneously.

In addition, through the motif of cutting, the quoted lines of Catullus 62 can also be related with Catullus 66 depicting the story of the Coma Berenices, which poem is the quasi-translation of Callimachus' fragment 110. Similarly to the maidens' chorus of Catullus 62 and the Catullus of poem 11, the lock of the Egyptian queen complains about the coming about of a cutting, but - unlike the plucking occurring in the two poems mentioned above - it should be taken literally, as Berenice offered a lock of her hair as a votive gift to the gods in order to ensure the

\footnotetext{
${ }^{21}$ MiLLER (1994: 105).

22 HARdie (2012: 230).
} 
safe return of her husband, Ptolemy III Euergetes from his Syrian campaign. The cutting of the lock can be associated with a series of separations: on the one hand, it can recall the loss of the queen's virginity through its connection with wedding as there is a well-known ancient tradition primarily characteristic of the Greeks, according to which the bride gave offerings symbolizing the transition from childhood to adulthood to some female deities before the wedding ritual, and among these offerings was a lock of hair of the future wife as well. ${ }^{23}$ On the other hand, the motif can symbolize the temporary separation of wife and husband, the parting because of possibly forthcoming death and it can foreshadow the lock's future ascension from Earth to the sky. ${ }^{24}$ And as some of the lock's words show, somewhat comically at times (e.g. invita, o regina tuo de vertice cessi, carm. 66, 39), that it sees its cut-off as a violent act, it can be observed that the idea of marriage (along with that of the loss of innocence in the sexual sense) and that of aggression and death emerge jointly - and what is more, the source of violence is a woman, just as in the case of Catullus 11.

Considering all this, I will now turn to the Vergilian texts. As the Catullan poems examined above are intertextually connected - both separately and together, through combined reminiscences - with several Vergilian passages that can be related with the loss of innocence, I will focus on two of them that have yet received less scholarly attention in this regard, namely, a part of Damon's song in Eclogue 8 and the depiction of Camilla in Book 11 of the Aeneid.

Eclogue 8 shows similarity to Catullus 62 through its amoebaean character already, ${ }^{25}$ as, in Vergil's poem, the singing contest of two shepherds, Damon and Alphesiboeus comes alive. Besides this, the two poems are also interconnected by the central motif of marriage: the Catullan poem, as referred above, can be placed in the context of a wedding ritual, and the Damon of the Eclogue expresses his heartache felt for the future wedding of his sweetheart, Nysa and Mopsus. For this, the

\footnotetext{
${ }^{23}$ HubBard (2014: 73).

24 FANTUZZI-HUNTER (2004: 87-88).

${ }^{25}$ GOUD (1995: 23-24).
} 
shepherd scolds Amor for making the girl fall in love with Mopsus as follows:

Nunc scio, quid sit amor: duris in cotibus illum aut Tmaros aut Rhodope aut extremi Garamantes nec generis nostri puerum nec sanguinis edunt. incipe Maenalios mecum, mea tibi, versus. saevus amor docuit natorum sanguine matrem commaculare manus; crudelis tu quoque, mater: crudelis mater magis, an puer improbus ille? improbus ille puer; crudelis tu, quoque mater. (Verg. Ecl. 8, 43-50)

Now I know what Love is. He was born on Tmarus's hard stone, or Rhodope's or furthest Garamentes's, not of our race and blood.

My flute, begin the songs, of Maenalus, with me. Cruel Love taught Medea to stain a mother's hands in her children's blood: a cruel mother too. Was the mother crueller, or the Boy more cruel? He was cruel: a cruel mother too. (Transl. A. S. Kline)

Damon describes the god of love as a boy born on the coarse rocks of distant, bald lands and contests even those of his anthropomorphic attributes which are otherwise attached to him by the social conventions (nec generis nostri puerum nec sanguinis edunt, Ecl. 8, 45). ${ }^{26}$ Furthermore, the shepherd accuses Amor of teaching the mother (matrem) to foul her hands with the blood of her children (natorum sanguine), so he asks the question whether the mother is rather cruel (crudelis ... magis) or the boy (i.e. Amor) is evil-hearted (improbus). ${ }^{27}$ At the end, he even answers his own question: the boy is evil-hearted, as much as the mother is cruel.

\footnotetext{
${ }^{26}$ COLEMAN (1977: 239).

${ }^{27}$ The interpretation of the question as 'Is the mother crueler than the evil-hearted boy?' is also thinkable but, regarding the answer given to it, I prefer the interpretation included in the main text. For a more detailed analysis of the problem, see COLEMAN (1977: 240).
} 
As Michael Putnam points out, the connection between the Vergilian passage and lines 20-24 of Catullus 62 is made conspicuous by the parallels drawn by the mutual occurrence of the expressions crudelis, mater and either form of natus / nata, supported by the repetition of these words in the texts: ${ }^{28}$ the three-time occurrence of the expression crudelis in the quotation from the Eclogue accords with doublet crudelior - crudelius of the Catullan lines, in which the expression matris occurring twice can be paralleled with the repeated forms of matrem - mater in Damon's song. Furthermore, another similarity regarding repetition can also contribute to the interconnectedness of the two texts which does not arise from the overlap of the vocabularies, as the repetitions an puer improbus ille? / improbus ille puer in Vergil and complexu avellere matris / complexu matris ... avellere in Catullus are related with each other by a peculiar chiastic construction. However, the contexts of the two texts are different in a large measure: Catullus 62 describes Hesperus as cruel because he tears the daughter away from her mother's lap during the wedding ritual, while in Eclogue 8 the mother is cruel, ${ }^{29}$ but she is not specified. It seems that the expression mater can refer to different mothers in line 48 and lines 49-50 of the Eclogue: Coleman's commentary suggests that the mater of the latter lines can be identified with Venus, ${ }^{30}$ who can be crudelis because she - as the mother of Amor - is also the source of Damon's unrequited love. However, the mother of line 48 who has fouled her hands with her children's blood can obviously be recognized as the mythic figure of Medea by the reader, and this reading is also supported by an intertext - noticed by the commentaries of both Clausen and Coleman - as the phrase saevus amor recalls the fragment of Ennius' Medea exul in which the heroine is depicted as 'wounded by furious love' (Medea animo aegro amore saevo saucia, Med. fr. 89 M., 213). ${ }^{31}$ So, the connotations of wedding associated with violence and death only emerging implicitly, due to the nature of the ritual in Catullus 62 come to the fore emphatically in Vergil's poem, partly through the Ennian and Catullan

\footnotetext{
28 PUTNAM (1970: 273).

29 PUTNAM (1970: 273).

30 COLEMAN (1977: 239-240).

${ }^{31}$ Clausen (1994: 252), COLEMAN (1977: 239).
} 
intertexts, partly through the explicit mentioning of the infanticide. As Nysa appears as a puppet under the influence of Amor, becomes similar to Medea, and this can raise the reader's suspicion that Nysa, similarly to the Colchian princess, might cause death as well, namely that of Damon himself, whose suicide caused by his heartache seems a realistic possibility ${ }^{32}$ - thus, the new wife might lose her innocence in the legal sense along with her innocence in the sexual sense, even if she played a role in the shepherd's death indirectly and unwittingly. In this wise, unlike the idea emerging in Catullus 62, the woman preparing to wed may become not the endurer of a violent act but the source of it, the victim of which is a man - and, in this regard, the Vergilian passage can be paralleled with Catullus 11.

At this point, we should take into account another Catullan intertext of the quoted lines of Damon's song which is registered neither by the two aforementioned commentaries on the Eclogues nor the commentaries on Catullus by Fordyce and Quinn. Lines 6-9 of Catullus 63 depict Attis castrating himself in an ecstatic state and just becoming conscious the following way:

itaque ut relicta sensit sibi membra sine viro, etiam recente terrae sola sanguine maculans, niveis citata cepit manibus leve typanum, typanum tuum, Cybebe, tua, mater, initia (Cat. carm. 63, 6-9)

Then as he felt his limbs were left without their manhood, and the fresh-spilt blood staining the soil, with bloodless hand she hastily took a tambour light to hold, your taborine, Cybele, your initiate rite (Transl. L. C. Smithers)

The connection between the quoted lines and the part of the eclogue examined is made obvious by the similarity of the expressions sanguine ... commaculare - sanguine maculans. But while Medea - the mother appearing in line 48 of Eclogue 8 - fouls her hands (manus) with the blood of her children, Attis, after fouling the soil with his own blood, takes the

32 Putnam (1970: 272). 
light tympanum of a 'mother', Cybele - also known as Magna Mater into his hands (manibus), going into her service. The aspect of key importance for my study is the self-mutilation of Attis, as it results in his transformation from man to woman, ${ }^{33}$ which is explicitly expressed in the text by the feminine ending of the participle excitata referring to him. So, as a result of a cutting, a fundamental change comes about: the alteration of the protagonist's gender. This momentum relates Catullus 63, on the one hand, with carmen 11, in which the mowing of the flower symbolizing Catullus' love felt for Lesbia can result in the inversion of the sexual roles, and, on the other hand, with Catullus 66, as the lock of Berenice also complains about being a victim of an aggressive act (i.e. the cutting of the lock) committed by a woman, so the traditional male and female roles get reversed regarding aggressiveness in this case as well. ${ }^{34}$ Considering this, it seems that the shift of emphasis from the aggressiveness of the man to that of the woman - emerging occasionally in the Catullan poems mentioned above and linked closely between each other both thematically, intertextually and regarding the stock of motives - culminates in Eclogue 8, thanks to the highlighting of Medea's cruelty (which possibly takes shape in another cutting).

Although the role of the interconnectedness of violence and sexuality in the Aeneid was studied closely by some scholars in the $1980 \mathrm{~s}^{35}$ the matter of virginity has so far received much less attention. ${ }^{36}$ As Robin $\mathrm{N}$. Mitchell argues, all of the virgin characters (either female or male) of the second half of the epic - unfolding a war for a marriage - are either the causes or the endurers of destruction, ${ }^{37}$ which is primarily the result of

\footnotetext{
${ }^{33}$ HARDIE (2012: 228).

${ }^{34}$ In his study Virgil's Catullan Plots, Philip HARDIE examines the combined allusions of these (at least) three Catullan poems in the Aeneid regarding the issue of chopping and changing in detail but he does not involve Eclogue 8 in this regard. See HARDIE (2012: 225-235).

35 See e.g. GILLIS (1983) and PUTNAM (1985).

36 Primarily, Don FowLER's study Vergil on Killing Virgins (1987), Robin N. MitCHELL's paper The Violence of Virginity in the Aeneid (1991) and Ellen OLIENSIS' article Sons and Lovers: sexuality and gender in Virgil's poetry (1997) deal with this topic.

37 Mitchell (1991: 219).
} 
losing the chance to consummate their sexuality (e.g. Euryalus, ${ }^{38}$ Pallas and Turnus) or of giving it up voluntarily (e.g. Camilla), so they ease their tensions of sexual abstinence in the form of aggression. ${ }^{39}$ However, the phenomenon is also conspicuous that the Vergilian text gets in touch with one or more Catullan poems of essential importance regarding the issue of my analysis when depicting the violent deeds of the epic heroes / heroines mentioned above or the aggression endured by them - for example, the intertextual connections between the passage of the Aeneid describing the death of Pallas and carmina 62 and 11 are well known. ${ }^{40}$

In contrast, the Catullan background of the passage describing Camilla in Book 11 has received less scholarly attention. From lines 576592 the reader can learn both about the virginal character and the pugnaciousness of Camilla:

Pro crinali auro, pro longae tegmine pallae

tigridis exuviae per dorsum a vertice pendent.

Tela manu iam tum tenera puerilia torsit

et fundam tereti circum caput egit habena

Strymoniamque gruem aut album deiecit olorem.

Multae illam frustra Tyrrhena per oppida matres

optavere nurum; sola contenta Diana

aeternum telorum et virginitatis amorem

intemerata colit. Vellem haud correpta fuisset

militia tali, conata lacessere Teucros:

cara mihi comitumque foret nunc una mearum.

Verum age, quandoquidem fatis urgetur acerbis,

labere, nympha, polo finisque invise Latinos,

tristis ubi infausto committitur omine pugna.

\footnotetext{
${ }^{38}$ The events leading to the death of Euryalus show great similarity to those of a marriage: first, as a bride puts on her wedding dress, he puts on the ornate armament taken from his slaughtered enemies (cf. Aen. 9, 359-366); then, comparably to the raptio, he gets captured by the men of Volcens (cf. Aen. 9, 396-398); and finally, described by a combined allusion to Catullus 62 and 11 (purpureus veluti cum flos succisus aratro / languescit moriens, Aen. 9, 435-436), his death can be paralleled with the virgin's defloration.

${ }^{39}$ MitChelL (1991: 221).

${ }^{40}$ MitChelL (1991: 228-229).
} 
Haec cape et ultricem pharetra deprome sagittam: hac quicumque sacrum violarit volnere corpus, Tros Italusque, mihi pariter det sanguine poenas. (Verg. Aen. 11, 576-592)

A tiger's pelt hung over head and down her back instead of a gold clasp for her hair, and a long trailing robe.

Even then she was hurling childish spears with tender hand, whirling a smooth-thonged sling round her head, bringing down Strymonian cranes and snowy swans. Many a mother in Etruscan fortresses wished for her as a daughter-in-law in vain: she, pure, content with Diana alone, cherished her love of her weapons and maidenhood. I wish she had not been swept up into such warfare, trying to challenge the Trojans: she would be my darling, and one of my company still. Come now, nymph, since bitter fate drives her on, slip from the sky and seek out the Latin borders, where with evil omen they join in sad battle.

Take these weapons and draw an avenging arrow from the quiver, and if anyone violates her sacred flesh by wounding her, Trojan or Italian, pay me with their equal punishment in blood. (Transl. A. S. Kline)

According to the words of the Vergilian Diana, the heroine - unlike the other girls - used to hunt birds already as a fragile little girl, hurling spears made for boys (tela ... puerilia) and whirling a sling, and she wears no golden clasp (crinali auro) or a woman's robe but a tiger's pelt hangs from her head (a vertice). Because of her virtues, many mothers wish for her (multae ... matres / optavere) as a daughter-in-law throughout the Tyrrhenian cities - but Camilla has been leading an immaculate life, giving herself up only to weapons and the 'love' felt for her virginity.

The quoted passage of the Aeneid gets in touch with three Catullan poems: on the one hand, the expression multae illam ... optavere of lines 581-582 recalls lines 42 and 44 of Catullus 62 (multi illum pueri, multae optavere puellae and nulli illum pueri, nullae optavere puellae), which parallel is registered by Fordyce in his commentary on Catullus and by 
Gransden in his commentary on the Aeneid, along with the connection of these texts with the story of Narcissus in Ovid's Metamorphoses (Ovid. Met. 3, 353-355) ${ }^{41}$ Both passages tell about the desires of many, and, as a matter of fact, the objects of these desires can be matched with each other as well: in the Catullan passage it is the flower symbolizing a virgin and in the Vergilian one it is Camilla herself. However, an important difference can also be observed: in Catullus 62, young boys and girls desire the flower (and of course, in a figurative sense, the man desires the maiden), so the sexual aspects of desire are dominant, while in the passage of the Aeneid the mothers (matres) desire Camilla as their daughter-in-law, consequently, the nature of the desires is not (or not directly) sexual in this case. Furthermore, the mentioning of the mothers recalls the repetition of the word matris in lines 21-22 of Catullus 62, and this tinges the difference between the contexts: in the case of the Catullan poem, harm is caused to the mother as her daughter gets torn from her during the wedding ceremony, while in the Vergilian passage we read that those are the mothers who hope that Camilla would get married to one of their sons and therefore she will be forced to part from her own mother. The intertext can prove to be proleptic considering that Camilla will 'fade' as the symbolic flower of Catullus 62 at the end, but her defloration will result in her separation from her life, not from her virginity.

On the other hand, the image pro crinali auro ... tigridis exuviae ... a vertice pendent emerging in lines 576-577 of the Vergilian text can be related with line 39 of Catullus 66 (invita, o regina tuo de vertice cessi, carm. $66,39)$, which connection is noticed neither by any of the authoritative commentaries on Catullus or the Aeneid nor by those studies of Philip Hardie and Jeffrey Wills ${ }^{42}$ which examine the intertextual interconnectedness of Catullus 66 and the Aeneid the most expansively. ${ }^{43}$ In the Vergilian text, the joint occurrence of the expressions crinali-derived from

\footnotetext{
${ }^{41}$ FORDYCE (1961: 259), GRANSDEN (2008: 120).

42 See HARDIE (2012) and WILLS (1998).

${ }^{43}$ Line 39 of Catullus 66 gets recalled more directly elsewhere in the Aeneid, e.g. in the passage of Book 6 describing the reunion of Aeneas and Dido: invitus regina tuo de litore cessi (Aen. 6, 460).
} 
the word crinis ('hair') - and a vertice can recall the separation of the lock of Berenice from the queen's head (de vertice). ${ }^{44}$ However, the context could hardly be more different: the hair of Camilla is not even mentioned, its idea can only emerge through the reference to the absence of the clasp; in contrast, the lock of Berenice is not just the central motif of Catullus 66 but it is the narrator as well. The queen has cut the lock off her head (de vertice) to which it belonged by nature - on the other hand, the Amazon has a tiger's pelt hanging from her head (a vertice) which befits an average maiden the least. However, as I have already mentioned, the cutting of the lock appears as some kind of aggression in Catullus 66, accompanied by the associations of marriage. Violence bound up inseparably with the figure of Hesperus and the future husband in Catullus 62 becomes the characteristic of a woman thanks to a cutting both symbolizing and bringing about a change in poem 66, and this can be of crucial importance regarding the Camilla episode as well, since the inversion of the usual sexual roles already emerging in the Catullan texts is completed in the case of the Vergilian heroine: her way of life and appearance resembles those of a man, she used to hunt hurling puerilia tela already as a child, violence is an essential component of her life to which men facing her on the battlefield fall prey - so, in this regard, the passage depicting Camilla can be paralleled with the last lines of Catullus 11 as well. On the other hand, in comparison with the Catullan texts, it can be mentioned as a significant difference that aggression is not accompanied by marriage in the case of Camilla - quite on the contrary, preserving her innocence in the sexual sense can result in her aggressiveness, because of which she cannot be considered as innocent in the legal sense.

Finally, the expression det sanguine poenas of line 592 recalls the closure of Catullus 116, an epigram written against Gellius, whose friendship with Catullus was ruptured because he - according to Catullus 91 had seduced the poet's lover:

\footnotetext{
${ }^{44}$ The word crinis occurs a few lines below in the Catullan poem as well (quid facient crines, cum ferro talia cedant?, carm. 66, 47).
} 
contra nos tela ista tua evitamus amictu

at fixus nostris tu dabis supplicium

(Cat. carm. 116, 7-8)

Now in return I will parry those missiles of yours by wrapping my cloak round my arm; but you shall be pierced by mine and punished. (Transl. F. Warre Cornish)

While Camilla hurled actual spears as a little girl, Gellius and Catullus throw tela at each other in the sense of verbal or written vituperation. On this basis, Gellius' punishment promised by Catullus (dabis supplicium) presumably means that Gellius will be the target of mockery thanks to the insults of the poet, so these 'missiles' cause not physical but psychical harm to their victim. On the contrary, Diana's words commanding the nymph Opis to punish anyone who dares to violate the body of Camilla reflect that 'punishment' means death in this case (det sanguine poenas). However, to be able to examine the intertextual interplay of these passages more extensively, we also have to take their literary antecedent into account, as these texts can be traced back to a fragment of Ennius' Annals. ${ }^{45}$ In lines $94-95$ of the epic, ${ }^{46}$ Romulus speaks his final words to his twin brother Remus before killing him because of jumping over the new city wall:

Nec pol homo quisquam faciet impune animatus

Hoc nec tu: nam mi calido dabis sanguine poenas.

(Enn. Ann. 94-95)

Neither you nor any man alive shall do this unpunished: no, you shall give recompense to me with your life-blood.

(Transl. E. H. Warmington)

Regarding Catullus and Ennius, besides the verbal parallel of dabis supplicium and dabis sanguine poenas, the connection of the two texts are also emphasized by a metrical phenomenon, i.e. the dropping of the final $s$

\footnotetext{
45 SKUTSCH (1985: 241).

46 I follow the numbering of Otto von SKUTSCH.
} 
during scansion. ${ }^{47}$ As W. Jeffrey Tatum observes, through the Ennian reminiscence, 'Catullus assumes the role of Rome's violent founder, thereby consigning Gellius to play the part of the twin who made himself the ultimate outsider. The switch in status is part of the sting. ${ }^{\prime 48}$ Nevertheless, the Catullan text also softens the lethal threatening of the Ennian fragment by promising supplicium to Gellius in the sense of shame. Concerning the type of recompense, by mentioning a real deadly missile (sagittam) and paying punishment in blood (det sanguine poenas), the quoted part of the Aeneid could be read as a text both 'correcting' the Catullan and 'confirming' the Ennian ones. However, if we consider the circumstances of the death of Arruns, the murderer of Camilla, another possible reading emerges, according to which it seems that he has to endure both kinds of punishment: after throwing a spear at the Amazon, he runs away in fear of revenge taken on him (cf. Aen. 11, 806-815), thereby bringing such a great shame upon himself that even his companions leave him alone while he is dying, shot by the arrow of Opis (illum exspirantem socii atque extrema gementem / obliti ignoto camporum in pulvere linquunt, Aen. 11, 865-866). Therefore, he becomes an outsider just like Remus and Gellius, but - more importantly - female aggression (sc. that of Diana and her agent Opis) can also be paralleled with male violence (sc. that of Romulus) again.

As we have seen, in Catullus 62, 66 and 11 - three poems primarily related with each other through the topic of losing virginity -, the vio-

${ }^{47}$ Line 8 of Catullus 116 gives the only example of this phenomenon in the Catullan corpus and the last one in Latin poetry, see ZETZEL (1983: 256). Béla ADAMIK questions the Catullan allusion to Ennius for two reasons: on the one hand, because of a varia lectio of the Ennian fragment known from Macrobius (das sanguine poenas), according to which there would be no metrical parallel between the two passages in question, and, on the other hand, as he supposes that the model of the Catullan line was not Ennius but Terence (et dabis / ultro supplicium, Eun. 69-70), on the basis of closer verbal similarities, see ADAMIK (2014: 164). In my opinion, the question is not whether the model of the Catullan line was Ennius or Terence but whether it can recall the Ennian fragment or not. Even if we cannot be sure about the metrical parallel because of the above mentioned varia lectio, and even if the Catullan passage shows closer verbal conformity to the Terentian text, I believe that it can recall Ennius as well, thanks to the similarity of their content.

48 TATUM (1997: 500). 
lent nature of defloration gets a special emphasis. In all of these poems, the motif of cutting plays an important role, symbolizing transition, provisionality and implying aggression at the same time. As cutting is carried out by women in Catullus 11 and 66, changing is also reflected in the inversion of sexual roles in these poems. Although the Catullan intertexts do not alter the possibilities of interpreting the examined passages of Eclogue 8 and the description of Camilla in the Aeneid radically, they prove to be significant, as, in the case of the Vergilian depiction of Medea and Camilla, they acutely draw the reader's attention to the phenomenon of associating violence - which is usually a masculine characteristic - with women. In the case of Medea, this could be handled easier by the contemporary reader, as she always had been 'different', a stranger from the barbaric East, but in the case of Camilla, an aboriginal Italian (decus Italiae virgo, Aen. 9, 508), this kind of approach could - at least as a modern reader would presume - make the Roman audience seriously reconsider the traditional gender roles.

\section{Sources}

A. S. KLINE: The Aeneid. Virgil. A translation into English prose by A. S. Kline. 2014.

A. S. KLINE: Virgil: The Eclogues. 2011.

https://www.poetryintranslation.com/PITBR/Latin/VirgilEclogues.php. 2020. 12. 05.

L. C. SMithers: The Carmina of Caius Valerius Catullus. London 1894.

E. H. WARMINGTON: Collected Fragments of Ennius. Hastings 2018.

F. WARre Cornish: The Poems of Gaius Valerius Catullus. Cambridge 1904.

\section{Bibliography}

ADAMIK 2014

B. ADAMIK: Zur Prosodie, Metrik und Interpretation von Catulls Carmen 116. Wiener Studien 127 (2014) 151-164.

Clausen 1994 W. V. Clausen (ed.): A Commentary on Virgil: Eclogues. Oxford 1994.

COLEMAN $1977 \quad$ R. COLEMAN (ed.): Vergil: Eclogues. Cambridge 1977.

CUller 2015 J. CULLER: Theory of the Lyric. Cambridge, MA 2015.

FANTUZZI-HUNTER 2004

M. FANTUZZI - R. HUNTER: Tradition and Innovation in Hellenistic Poetry. Cambridge 2004.

FORDYCE 1961 C. J. FORDYCE (ed.): Catullus. A Commentary. Oxford 1961. 
FOWLER 1987

GENNEP 1909

GILLIS 1983

GOUD 1995

GRANSDEN 2008

GREENE 2007

HARDIE 2012

HERSCH 201

HUBBARD 2014

MILLER 1994

MITCHELL 1991

OLIENSIS 1997

PANOUSSI 2007

PUTNAM 1970

PUTNAM 1985

SKUTSCH 1985

SZILÁGYI 2011

TATUM 1997

THOMSEN 2002

WILLS 1998

ZETZEL 1983
D. FOWLER: Vergil on Killing Virgins. In: M. Whitby - P. Hardie M. Whitby (eds.): Homo Viator: Classical Essays for John Bramble. Bristol 1987, 185-198.

A. van GENNEP: Les rites de passage. Paris 1909.

D. GILLIS: Eros and Death in the Aeneid. Rome 1983.

T. GOUD: Who Speaks the Final Lines? Catullus 62: Structure and Ritual. Phoenix 49/1 (1995) 23-32.

K. W. GransDen (ed.): Virgil: Aeneid, Book XI. Cambridge 2008.

E. GReEnE: Catullus and Sappho. In: M. Skinner (ed.): A Companion to Catullus. Malden, MA 2007, 131-150.

P. HARDIE: Virgil's Catullan Plots. In: I. Du Quesnay - T. Woodman (eds.): Catullus. Books, Poems, Readers. Cambridge 2012, 212238.

K. K. HERSCH: The Roman Wedding. Ritual and Meaning in Antiquity. Cambridge 2010.

T. K. HubBARD (ed.): A Companion to Greek and Roman Sexualities. Malden, MA, Oxford, Chichester 2014.

P. A. Miller: Lyric Texts and Lyric Consciousness. London, New York 1994.

N. R. Mitchell: The Violence of Virginity in the Aeneid. Arethusa 24/2 (1991) 219-238.

E. OlIENSIS: Sons and Lovers: sexuality and gender in Virgil's poetry. In: C. Martindale (ed.): The Cambridge Companion to Virgil. Cambridge 1997, 294-311.

V. PANOussi: Sexuality and Ritual: Catullus' Wedding Poems. In: M. Skinner (ed.): A Companion to Catullus. Malden, MA 2007, 276292.

M. C. Putnam: Virgil's Pastoral Art. Princeton 1970.

M. C. Putnam: Possessiveness, Sexuality and Heroism in the Aeneid. Vergilius 31 (1985) 1-21.

O. von SKUTSCH (ed.): The Annals of Quintus Ennius. Oxford 1985.

J. Gy. SzILÁGYi: Erós, Dionysos, Thanatos. In: J. Gy. Szilágyi: A tenger fölött [Above the Sea]. Budapest 2011, 235-239.

W. J. TAtuM: Friendship, Politics, and Literature in Catullus: Poems 1, 65 and 66, 116. The Classical Quarterly 47/2 (1997) 482-500.

O. ThOMSEn: An Introduction to the Study of Catullus' Wedding Poems: The Ritual Drama of Catullus 62. C\&M 53 (2002) 255-287.

J. WILls: Divided Allusion: Virgil and the Coma Berenices. Harvard Studies in Classical Philology 98 (1998) 277-305.

J. E. G. Zetzel: Catullus, Ennius and the Poetics of Allusion. Illinois Classical Studies 8 (1983) 251-266. 